\title{
How Does the Urban Environment Affect Health and Well-Being? A Systematic Review
}

\author{
Anne Caroline Krefis ${ }^{1, *}$, Matthias Augustin ${ }^{1}$, Katharina Heinke Schlünzen ${ }^{2}$, \\ Jürgen Oßenbrügge $^{3}$ and Jobst Augustin ${ }^{1}$ \\ 1 Institute for Health Services Research in Dermatology and Nursing (IVDP), University Medical Center \\ Hamburg-Eppendorf (UKE), Martinistr. 52, 20246 Hamburg, Germany; m.augustin@uke.de (M.A.); \\ jo.augustin@uke.de (J.A.) \\ 2 Meteorological Institute, Centrum für Erdsystemforschung und Nachhaltigkeit (CEN), Universität \\ Hamburg, Bundesstr. 55, 20146 Hamburg, Germany; heinke.schluenzen@uni-hamburg.de \\ 3 Institute of Geography, Centrum für Erdsystemforschung und Nachhaltigkeit (CEN), Universität Hamburg, \\ Bundesstr. 55, 20146 Hamburg, Germany; juergen.ossenbruegge@uni-hamburg.de \\ * Correspondence: a.krefis@uke.de; Tel.: +49-040-741-55349
}

Received: 22 January 2018; Accepted: 28 February 2018; Published: 2 March 2018

\begin{abstract}
In times of rapid urbanization, health and well-being of citizens is increasingly recognized as a challenge. A remarkable amount of research on relations between urban environments and health or well-being has been conducted. To get an insight about the existing measurements on both health combined with well-being, a systematic literature search was conducted using the databases PubMed and ScienceDirect including references until July 2017. To classify the references a conceptual model describing interrelationships between factors that may be associated with health-related urban well-being was used. The keywords "urban", "well-being", and "health" were applied together with factors described in the model. Twenty-four articles met the inclusion criteria. Of these, most studies focused on associations between urban green, health and well-being showing the great importance of green space usage in urban settings to promote better health and well-being. Health was mostly assessed by the General Health Questionnaire (GHQ-12); to measure well-being, the Warwick-Edinburgh Mental Well-Being Scale (WEMWBS) was mostly used. There are still only a few studies investigating the great complexity of urban health and well-being. More specifically, there is a lack in interdisciplinary approaches that highlight the complexity of urban structures and dynamics and their possible influence on urban health and well-being.
\end{abstract}

Keywords: urban environment; health; well-being; UrbWellth; review

\section{Introduction}

Nowadays, more than $50 \%$ of the population worldwide lives in urban areas. This number might rise to more than $70 \%$ by 2050 [1]. Cities provide some of the worst as well as some of the best environments for health and well-being [2]: Challenges posed by rapid global urbanization, are caused by increasing environmental stressors or increasing socioeconomic disparities and are associated with urban health and urban well-being. On the other side the so-called "urban advantages" describe the health and well-being benefits by living in cities as opposed to rural regions [3-5].

A remarkable amount of research has been conducted by several disciplines, including public health, urban planning, natural sciences (e.g., meteorology) or epidemiology, on the potential associations between urban areas and health or well-being. There are different institutions with projects worldwide: The World Health Organization (WHO) for instances focuses on "healthy cities networks" [6,7], The London School of Economics and Political Science (LSE) has a project on "Cities, health and well-being" [2,6], and the Healthy People 2020 organization monitors "Health-related 
Quality of Life and Well-Being" in the US [7]. Furthermore, the International Council for Science (ICSU) with their "Science plan on Health and Wellbeing in the Changing Urban Environment" [8,9] focus on this issue and underline the importance for "shaping cities for health" [4].

Key messages or recommendations from all these institutions aim to improve urban health and well-being, to recognize and reduce inequalities in health outcomes, as well as to build capacity on national and on regional levels to promote urban health and well-being [2,4,6-8,10].

However, the term "well-being" has a multi-faceted nature, which can be defined and measured in a variety of ways [11,12]. The definition for well-being is still challenging, whereby the terms "happiness", "life satisfaction" or "quality of life" are often used in the same context [11,13]. Specifically, the association between well-being and urban health is ambiguous and needs to be specified. The authors use the definition described in Szombathely et al., 2017 [14] where a conceptual model was developed. The model describes possible interrelations and interactions of factors and risks that may be associated with urban health and well-being, in particular targets on cities of the global north. It relates the determinants to four different sectors (individual, society, stressors, and morphology), and associates these to health-related urban well-being (UrbWellth), which considers domains that are associated with individual physical (objective health status), mental (subjective health status), and emotional (affective well-being) aspects of health, with natural (e.g., climate) and urban specific environment (e.g., public parks) as well as with political systems (e.g., urban governance), social functioning (e.g., neighborhood), and social context (e.g., social position) in which the urban population lives $[13,14]$. More details on the factors and interrelations considered in the conceptual model and their impacts on UrbWellth can be found at Szombathely et al., 2017 [14].

Measuring UrbWellth can be conducted by involving objective as well as subjective indicators. Objective indicators can be values for income, crime rates or environmental factors such as noise or air pollution and can be obtained by using official (external) sources such as census data.

Over the past decades there has been a growing research on subjective (internal) indicators of urban health and well-being, which are based on social survey data and used among other self-reported scores $[12,13,15]$. However, most of the studies describe or analyze either associations between urban determinants and health in general [3-5], specific urban determinants and health, such as associations of noise $[16,17]$ or air pollution $[18,19]$ on health, or associations between urban environments and well-being, such as associations between access to urban parks [20,21] or multiple stressors [22] and well-being.

As combined data on urban health and urban well-being are lacking, the objective of this paper is to summarize the literature on the objective and subjective measurements and methods on health-related urban well-being and their main findings as well as on projects dealing with particular aspects of UrbWellth.

\section{Materials and Methods}

The literature search conducted was finalized in June 2017. The literature search focused on studies conducted in the last ten years (2007 to 2017). To allow for comparability and transferability to the conceptual model the search was restricted to studies conducted for European cities or cities located in northern America with a population of 500,000 to 10 million.

For the systematic literature search the two databases PubMed as well as ScienceDirect were chosen. PubMed was selected to cover publications with a medical or health focus. ScienceDirect covered publications on natural sciences.

First, we searched for articles published in English since 2007 that included in their title or abstract the keywords:

(urban OR city OR municipality) AND (wellbeing OR well-being) AND (health), respectively.

Second, we selected articles that measure health and well-being (life-satisfaction, (health-related) quality of life) in an urban setting and are related to one of the determinants or sectors (individual, society, stressors, or morphology) of the conceptual model (Figure 1). 


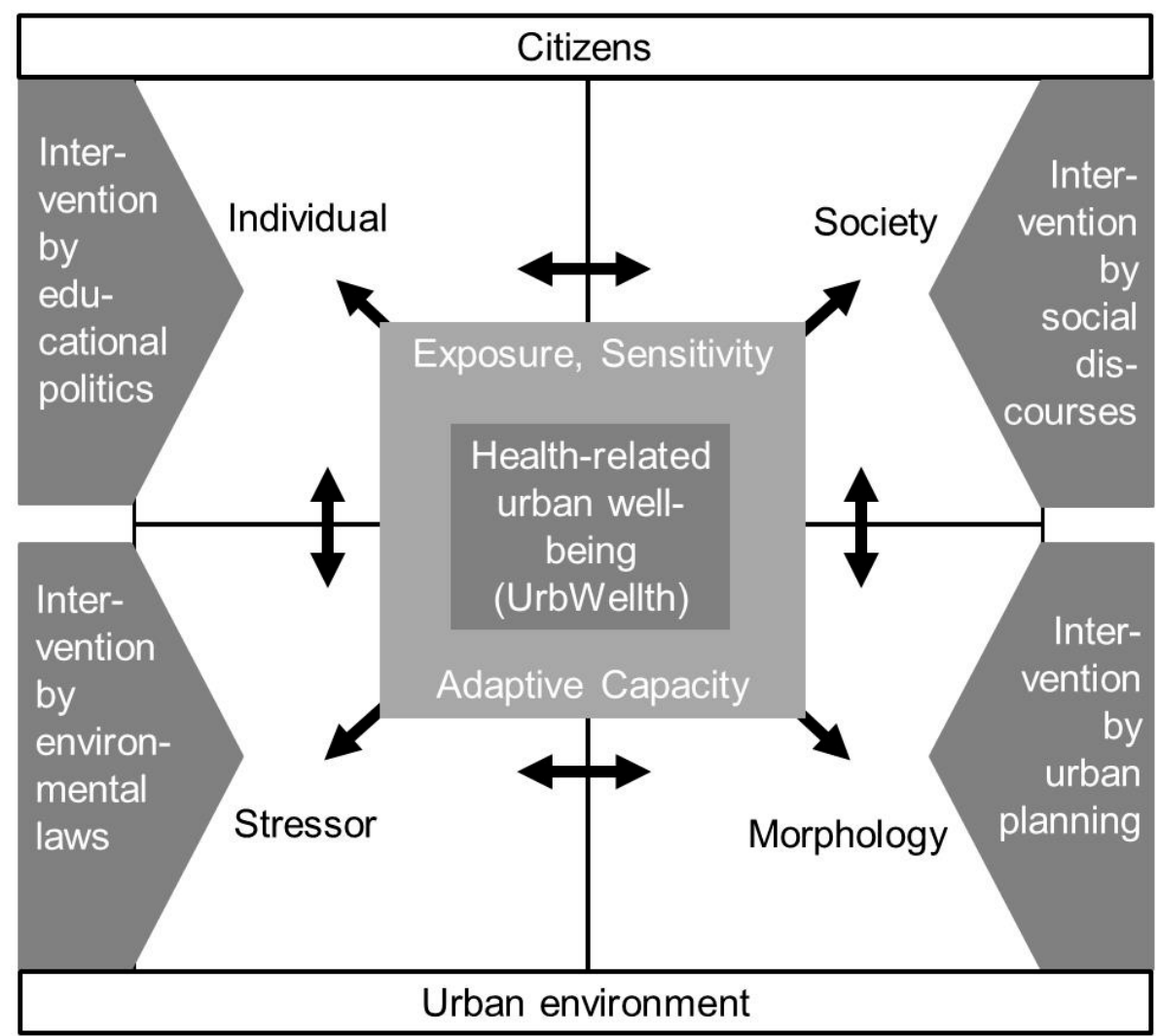

Figure 1. Sectoral influences on health-related urban well-being (UrbWellth). Simplified sketch based on Figure 3 of [14]. This structure is used as a basis for the systematic literature search. Determinants of the sectors are given in [14] and described in the next section in detail.

The search algorithm for health-related urban well-being together with the determinants in the "individual" sector as described in [14] was as follows:

(urban OR city OR municipality) AND (wellbeing OR well-being) AND (health)

AND (income OR education OR smoking OR alcohol OR gender OR age OR nutrition OR clothing OR "physical constitution" OR "mental constitution" OR habituation OR "other disposition").

For the "society sector" the search algorithm [14] was:

(urban OR city OR municipality) AND (wellbeing OR well-being) AND (health)

AND (security OR "social network" OR "mobility lifestyle" OR household OR supply OR work OR leisure OR "modes of transport").

Articles covering UrbWellth together with factors from the "morphology sector" [14] were searched by the algorithm:

(urban OR city OR municipality) AND (wellbeing OR well-being) AND (health)

AND ("green spaces" OR "blue spaces" OR "public places" OR "transport infrastructure" OR buildings OR "building structure" OR "public infrastructure" OR "health infrastructure" OR emitters).

Finally, to cover articles from the "stressors sector" [14] the following search algorithm was used: (urban OR city OR municipality) AND (wellbeing OR well-being) AND (health)

AND (noise OR "thermal environment" OR "UV-Radiation" OR "air pollutants" OR temperature OR humidity OR precipitation OR wind).

From the databases only full texts, which were available for the authors, were considered.

Study inclusion was determined by one researcher in three steps, supported randomly by a second researcher. In the first step, the researchers screened title and abstract of the articles resulted from the literature search related to the inclusion criteria. In a second step, articles were screened based on 
the full text and assessed for eligibility. In a third step, articles were reviewed regarding projects and methods that have been used to assess UrbWellth (Figure 2).

Finally, included articles were categorized into studies measuring UrbWellth combined with factors from the individual-, society-, morphology- and stressor sector, respectively.

\section{Results}

\subsection{Study Selection}

The initial electronic database search in PubMed and ScienceDirect resulted in $n=770$ and $n=481$ hits, respectively. From these, 193 duplicate records were removed. A total of 965 articles were excluded based on title or abstract and not being conducted in the European region or northern America or with no city size meeting the criteria (Figure 2). As a result, 93 full texts were reviewed in detail and assessed for eligibility. In conclusion, 24 full-text articles were included describing studies, in which urban health combined with well-being was measured.

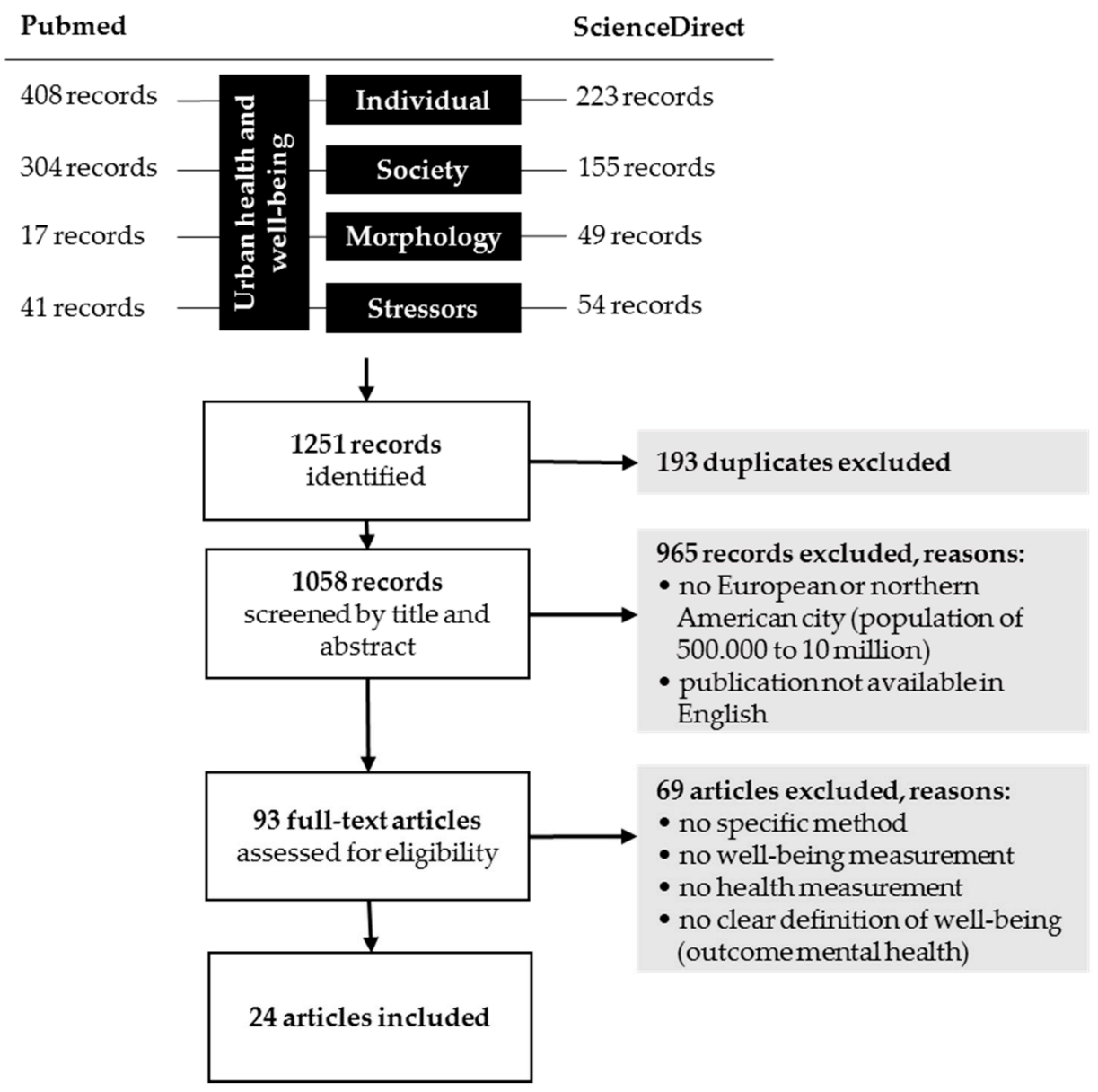

Figure 2. Search flow showing literature search results on UrbWellth articles found at the PubMed and ScienceDirect database, published 2007 to July 2017.

In a next step, all the considered articles were assigned to one of the sectors described in the conceptual model (Figure 1). However, it must be noted that in most of cases publications were included in more than one of the four sectors. As it can be seen in Figure 1, all sectors are interrelated, for instance the individual and society sectors are associated with each other, and so are society and morphology. These interrelations become obvious in the considered publications (e.g., studies analyzing individual and neighborhood factors on health and well-being), which sometimes made it difficult to allocate the papers to the respective sectors. Table 1 lists all articles and their respective 
allocation to one of the four sectors: the main sector (identified by the heading) is marked (" $x$ "), additional sectors are marked (" $\mathrm{o}$ ") if (parts of the) factors covered by the respective sector were considered in the study. However, all papers were assigned to the sector where the authors sought it is most suitable.

Table 1. Allocation of all studies to the respective sectors*.

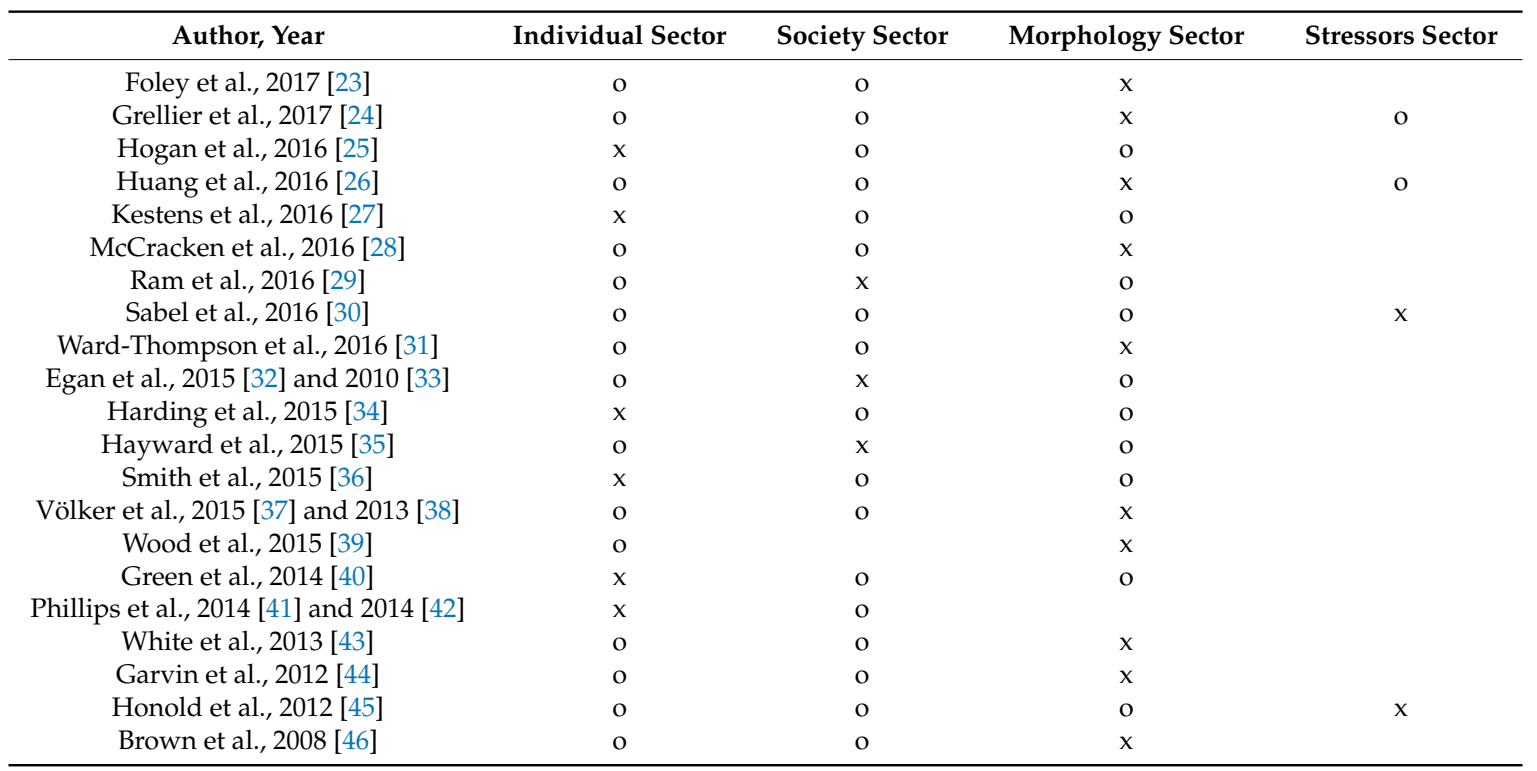

* The main sector (identified by the heading) is marked " $\mathrm{x}$ ", additional sectors are marked "o" if factors covered by the respective sector were considered in the study.

\subsection{Studies on UrbWellth-The Individual Sector}

Table 2 summarizes the studies relating UrbWellth to the individual sector described in the conceptual model. Most studies were conducted in London; Phillips et al., 2014 describe main results of a cluster-randomized trial of Well London, Phase- 1 having a focus on improving healthy physical activity, healthy eating, and well-being of adults in multiply deprived communities in the city of London. Primary outcomes (a General Health Questionnaire (GHQ)-12 score and a Warwick Edinburgh Mental Well-Being Scale (WEMWBS)) were measured by a post-intervention questionnaire survey. However, interventions towards healthy diet (five portions fruits or vegetables/day; $5 \times 30 \mathrm{~min}$ of moderate-level physical activity/week) did not improve health behaviors, well-being, and social outcomes [41,42].

Inequalities in adulthood and the herein resulting health and well-being consequences may be already initiated in childhood. Some cities or boroughs have a relatively young population and this proportion might even increase suggesting that the identification of determinants of adolescent health and hence, consequent interventions might result in reducing inequalities in later adult life [47]. One exemplary borough with a high percentage of younger inhabitants is the borough "East London", UK, where several studies were conducted to investigate potential associations between individual and societal factors and adolescents' physical and psychological health. For example, the ORiEL (the Olympic Regeneration in East London) study where individual socio-demographic factors and the perceptions of the urban physical environment were assessed. By using, among others, the WEMWBS to assess positive mental well-being and the Youth-Physical Activity Questionnaire, main findings were an increase in better mental health as positive perceptions of the neighborhood safety, aesthetics, walkability, and services increased, whereas only a weak association was found between mental health and individual socio-demographic factors [36]. Same trends could be found by the RELACHS (Research with East London Adolescents: Community Health Survey) study [48,49]. 
Table 2. Studies on UrbWellth—the individual sector, years 2007-2017.

\begin{tabular}{|c|c|c|c|c|}
\hline Authors, Year, Study Area & Study Title & Design & UrbWellth Measurement & Main Findings \\
\hline $\begin{array}{l}\text { Hogan et al., } 2016 \text { [25], } \\
\text { Berlin, Germany; Paris; } \\
\text { France; London, UK; New } \\
\text { York, USA; Toronto, Canada }\end{array}$ & $\begin{array}{l}\text { Happiness and health across the lifespan in } \\
\text { five major cities: The impact of place and } \\
\text { government performance. }\end{array}$ & $\begin{array}{l}\text { Cross-sectional survey, } \\
\mathrm{N}=1286 \text { (aged 25-34 } \\
\text { years); } \mathrm{N}=1960 \\
(35-49) ; \\
\mathrm{N}=953(50-64) ; \\
\mathrm{N}=685(65-85)\end{array}$ & Quality of Life Survey & $\begin{array}{l}\text { Younger residents preferred better access to } \\
\text { cultural, shopping or sport amenities and an } \\
\text { attractive city (place variables), which was linked } \\
\text { to happiness and health. Happiness and health of } \\
\text { older inhabitants was associated with the } \\
\text { provision of quality governmental services } \\
\text { (performance variables). }\end{array}$ \\
\hline $\begin{array}{l}\text { Kestens et al., } 2016 \text { [27], } \\
\text { Montreal, Canada; Paris, } \\
\text { France; Luxembourg, } \\
\text { Luxembourg }\end{array}$ & $\begin{array}{l}\text { Understanding the role of contrasting } \\
\text { urban contexts in healthy aging: an } \\
\text { international cohort study using wearable } \\
\text { sensor devices (the CURHA study } \\
\text { protocol). }\end{array}$ & $\begin{array}{l}\text { Cohort study, } \\
\mathrm{N}=\text { still outstanding }\end{array}$ & $\begin{array}{l}\text { Combination of data from 7-day GPS and accelerometer } \\
\text { for daily mobility, 7-day diary of self-reported } \\
\text { destinations and social contacts for information about } \\
\text { transportation modes, destination types, and social } \\
\text { contacts, a socio-spatial questionnaire (VERITAS) for } \\
\text { e.g., location of regular destinations or social network } \\
\text { characteristics, qualitative assessment of mobility and } \\
\text { place experience (Go-along method), CAPI } \\
\text { questionnaires for numerous outcomes and control } \\
\text { variables including health and perceived environment } \\
\text { and GIS to depict among others land use or } \\
\text { neighborhood composition. }\end{array}$ & Still to be published. \\
\hline $\begin{array}{l}\text { Harding et al., } 2015 \text { [34], } \\
\text { London, UK }\end{array}$ & $\begin{array}{l}\text { The Determinants of young Adult Social } \\
\text { well-being and Health (DASH) study: } \\
\text { diversity, psychosocial determinants, and } \\
\text { health. }\end{array}$ & $\begin{array}{l}\text { Cohort study, } \mathrm{N}=6643 \\
(2002 / 2003) ; \\
\mathrm{N}=4782(2005 / 2006) ; \\
\mathrm{N}=665(2012-2014) ; \\
\text { aged 11-13 years }\end{array}$ & $\begin{array}{l}\text { Combination of qualitative interviews, physical } \\
\text { measures by trained field assistants/nurses, } \\
\text { self-completed questionnaires about socioeconomic and } \\
\text { psychosocial factors and health using the SDQ, a TDS, } \\
\text { the GHQ-12, and a PBI. }\end{array}$ & $\begin{array}{l}\text { Ethnic minority adolescents reported better menta } \\
\text { health than White British but had higher blood } \\
\text { pressure compared to White British. }\end{array}$ \\
\hline $\begin{array}{l}\text { Smith et al., } 2015 \text { [36], East } \\
\text { London, UK }\end{array}$ & $\begin{array}{l}\text { Individual socio-demographic factors and } \\
\text { perceptions of the environment as } \\
\text { determinants of inequalities in adolescent } \\
\text { physical and psychological health: the } \\
\text { Olympic Regeneration in East London } \\
\text { (ORiEL) study. }\end{array}$ & $\begin{array}{l}\text { Cross-sectional sample, } \\
\mathrm{N}=3105 \\
\text { (aged 11-12 years) }\end{array}$ & $\begin{array}{l}\text { Combination of a pseudo-anonymized paper-based } \\
\text { questionnaire including the WEMWBS for assessing } \\
\text { positive mental well-being, the Short Moods and } \\
\text { Feelings Questionnaire to assess depressive symptoms, } \\
\text { the Youth-Physical Activity Questionnaire, and a } \\
\text { self-assessment of general health and } \\
\text { longstanding illness. }\end{array}$ & $\begin{array}{l}\text { Mental health advantage in adolescents increased } \\
\text { as positive perception of neighborhood safety, } \\
\text { aesthetics, walkability, and services increased. } \\
\text { Same trends were found for general health. }\end{array}$ \\
\hline $\begin{array}{l}\text { Green et al., } 2014 \text { [40], } \\
\text { London, UK }\end{array}$ & $\begin{array}{l}\text { More than A to B: the role of free bus travel } \\
\text { for the mobility and wellbeing of older } \\
\text { citizens in London. }\end{array}$ & $\begin{array}{l}\text { Cross-sectional sample, } \\
\mathrm{N}=47 \text { (aged }>60 \text { years) }\end{array}$ & $\begin{array}{l}\text { Implementation of interviews in either individual } \\
(\mathrm{N}=14) \text {, dyad }(\mathrm{N}=12) \text { or small group }(\mathrm{N}=21) \text { settings. }\end{array}$ & $\begin{array}{l}\text { By using free bus travel older citizens can more } \\
\text { participate in life in the city, have more } \\
\text { possibilities for social interaction, increased health } \\
\text { well-being, and reduced chronic loneliness. }\end{array}$ \\
\hline
\end{tabular}


Table 2. Cont.

\begin{tabular}{|c|c|c|c|c|}
\hline Authors, Year, Study Area & Study Title & Design & UrbWellth Measurement & Main Findings \\
\hline $\begin{array}{l}\text { Phillips et al., } 2014 \text { [41] and } \\
2014 \text { [42], London, UK }\end{array}$ & $\begin{array}{l}\text { Well London Phase-1: results among adults } \\
\text { of a cluster-randomized trial of a } \\
\text { community engagement approach to } \\
\text { improving health behaviors and mental } \\
\text { well-being in deprived inner-city } \\
\text { neighborhoods/measures of exposure to } \\
\text { the Well London Phase-1 intervention and } \\
\text { their association with health, well-being } \\
\text { and social outcomes. }\end{array}$ & $\begin{array}{l}\text { Cluster-randomized-trial, } \\
20 \text { matched pairs of } \\
\text { neighbor-hoods, } \\
\mathrm{N}=3986 \text {. }\end{array}$ & $\begin{array}{l}\text { By using a post-intervention questionnaire survey, } \\
\text { primary outcomes (five portions fruits or } \\
\text { vegetables/day; } 5 \times 30 \text { min of moderate intensity } \\
\text { physical activity/week, GHQ-12 score, and WEMWBS } \\
\text { score) were measured. }\end{array}$ & $\begin{array}{l}\text { Interventions did not improve health behaviors, } \\
\text { well-being, and social outcomes. }\end{array}$ \\
\hline
\end{tabular}

CAPI: Computer-Assisted Personal Interviewing; GHQ-12: General Health Questionnaire (12 items); GIS: Geographic Information Systems; GPS: Global Positioning Systems; PBI: Parental Bonding Instrument; SDQ: Strengths and Difficulties Questionnaire; TDS: Total Difficulties Score; WEMWBS: Warwick-Edinburgh Mental Well-Being Scale. 
On the other side, cities must face an increasing aging population and hence, solutions to address global environmental and healthy aging issues. The CURHA (Contrasted Urban settings for Healthy Aging) project addresses these challenges by combining data from wearable sensors and interactive map-based applications together with classical questionnaires on well-being, physical activity, perceived environments, and qualitative assessment of experience of places. Data from three cohorts located in Montreal, Paris, and Luxembourg shall generate evidence about which characteristics of urban environments are associated with active mobility, social participation, and well-being [27]. One approach for healthier urban aging was suggested by Green et al. (2014) by investigating the impact of free bus travel on mobility and well-being of older citizens in London. By using free bus travel older citizens can increasingly participate in life in the city and have more possibilities for social interaction. Hence, free bus travel for older citizens can reduce chronic loneliness and increase health and well-being [40].

The potential impact of an urban environment on the health and "happiness" (term used in the title) of its inhabitants across the lifespan was investigated by Hogan et al. (2016) considering 5000 adults aged 25-85 years living in Berlin, Paris, London, New York, and Toronto. Respondents reported their happiness and health levels and evaluated their city along place (e.g., the beauty and the built environment of a city and access to amenities) and performance (e.g., services related to education, social services, or healthcare) by completing the Quality of Life Survey. Results revealed that for being happier younger residents preferred better access to cultural, shopping or sport amenities and an attractive city, which was also linked to health. Instead happiness and health of older inhabitants was associated with the provision of quality governmental services [25].

A city is a so-called melting pot for migrant populations and the increasing amount of ethnic minority groups, pose important challenges for many disciplines such as public health. Migrant populations, which reside in London, were the focus in the DASH (Determinants of young Adult Social well-being and Health) study. Results showed, that-in line with other studies [50,51]—ethnic minority adolescents reported better mental health than White British suggesting that this resilience might be explained by cultural factors. However, a less positive result could be detected for cardio-respiratory health outcomes such as ethnic minority groups had higher blood pressure compared to White British [34].

\subsection{Studies on UrbWellth—The Society Sector}

The conceptual model shows, that the society sector is closely linked to the individual sector as well as to the morphology sector (Figure 1). This close relation is reflected in the considered studies. All the studies included in the society sector analyzed individual factors (such as the socioeconomic and sociodemographic status of an individual) in combination with environmental factors describing for instance neighborhood safety or social networks (society sector) together with morphological factors such as changes in built environment and their potential impact on health behavior, general physical and psychological health, and well-being (Table 1).

The GoWell Research and Learning Programme was designed to investigate the impact of housing investment, regeneration, and neighborhood renewal on the health and well-being on residents in the city of Glasgow, UK. However, results were inconsistent suggesting that individual-level contextual differences, together with neighborhood-level factors and variations in intervention implementation of redesign might influence the perception of residents concerning their health and well-being [32,33].

The focus of a study conducted in Baltimore, United States, was to investigate how public housing residents perceive that the social and built environments might influence their health and well-being. Four themes which are related to the social and physical environment experienced by public housing residents were identified (Table 3 ) and it is concluded that residents should be empowered in facilitating neighborhood changes to improve health and well-being [35]. 
Table 3. Studies on UrbWellth—the society sector, years 2007-2017.

\begin{tabular}{|c|c|c|c|c|}
\hline $\begin{array}{c}\text { Authors, Year, Study } \\
\text { Area }\end{array}$ & Study Title & Design & UrbWellth Measurement & Main Findings \\
\hline $\begin{array}{l}\text { Ram et al., } 2016 \text { [29], } \\
\text { London, UK }\end{array}$ & $\begin{array}{l}\text { Cohort profile: Examining Neighborhood } \\
\text { Activities in Built Living Environments in } \\
\text { London: the ENABLE London-Olympic } \\
\text { Park cohort. }\end{array}$ & $\begin{array}{l}\text { Controlled cohort } \\
\text { study, } \mathrm{N}=1497\end{array}$ & $\begin{array}{l}\text { Combination of physical activity and } \\
\text { location data, anthropometry (Body mass } \\
\text { index), questionnaire data using among } \\
\text { others the EQ-5D to measure the general } \\
\text { health status, the "Neighborhood } \\
\text { Physical Activity Questionnaire" and } \\
\text { data from the Household Survey } 2011 .\end{array}$ & Still to be published. \\
\hline $\begin{array}{l}\text { Egan et al., } 2015 \text { [32] and } \\
2010 \text { [33], Glasgow, } \\
\text { Scotland, UK }\end{array}$ & $\begin{array}{l}\text { Neighborhood demolition, relocation, and } \\
\text { health. A qualitative longitudinal study of } \\
\text { housing-led urban regeneration in Glasgow, } \\
\text { UK/Protocol for a mixed methods study } \\
\text { investigating the impact of investment in } \\
\text { housing, regeneration and neighborhood } \\
\text { renewal on the health and wellbeing of } \\
\text { residents: the GoWell program. }\end{array}$ & $\begin{array}{l}\text { Qualitative } \\
\text { longitudinal study } \\
\text { including } 4 \text { survey } \\
\text { waves, up to } \\
\mathrm{N}=6008\end{array}$ & $\begin{array}{l}\text { Combination of qualitative interviews } \\
\text { about participant's living environment } \\
\text { and health behaviors, the SF-12 (Wave 1), } \\
\text { and from Wave } 2 \text { onwards the WEMWBS. }\end{array}$ & $\begin{array}{l}\text { Inconsistent results suggesting that } \\
\text { individual-level contextual differences, together } \\
\text { with neighborhood-level factors and variations } \\
\text { in intervention implementation of redesign } \\
\text { might influence the perception of residents } \\
\text { concerning their health and well-being. }\end{array}$ \\
\hline $\begin{array}{l}\text { Hayward et al., } 2015 \text { [35], } \\
\text { Baltimore, Maryland, USA }\end{array}$ & $\begin{array}{l}\text { Linking social and built environmental } \\
\text { factors to the health of public housing } \\
\text { residents: a focus group study. }\end{array}$ & $\begin{array}{l}\text { Focus group study, } \\
\mathrm{N}=28\end{array}$ & $\begin{array}{l}\text { Interviews conducted in six focus groups } \\
\text { to assess residents' perception of health } \\
\text { and neighborhood attributes, resources, } \\
\text { and social structure. }\end{array}$ & $\begin{array}{l}\text { Identification of four themes: } 1 \text {. Public housing's } \\
\text { unhealthy physical environment limits health } \\
\text { and well-being; } 2 \text {. The city environment limits } \\
\text { opportunities for healthy lifestyle choice; } 3 \text {. Lack } \\
\text { of trust in relationships contributes to social } \\
\text { isolation; } 4 \text {. Increased neighborhood social } \\
\text { capital might improve well-being. }\end{array}$ \\
\hline
\end{tabular}

EQ-5D: EuroQol five dimensions questionnaire; SF-12: Short Form 12 version 2 questionnaire; WEMWBS: Warwick-Edinburgh Mental Wellbeing Scale. 
The former London 2012 Olympics Athletes' Village is the setting for another study (see the ORiEL study described in the previous section). The objective of the ENABLE London (Examining Neighborhood Activities in Built Living Environments in London) controlled cohort study, is to analyze and evaluate associations between moving into social, intermediate and market rent accommodation in East London and physical activity, health, and well-being indicators. So far, data on physical activity patterns assessed by GPS (Global Positioning Systems), medical examination to assess body compositions, and detailed participant questionnaire providing for instance information on socioeconomic status, general health/health status, well-being, attitudes to leisure time activities and other personal, social, and environmental influences on mobility were collected in roughly 1000 households. Results might help to identify evidence-based design features of the built environment that encourage physical activity and improve health behaviors and well-being [29].

\subsection{Studies on UrbWellth-The Morphology Sector}

During the systematic literature search, most included studies were found dealing with potential associations between vegetation environments and urban health as well as well-being. Additionally, several reviews addressing this topic were found [52-55].

Most of the selected studies investigating the potential impact of urban green space on health and well-being (Table 4) were conducted in the UK. Ward-Thompson et al. (2016) for instance conducted a cross-sectional survey in four communities of high urban deprivation in Scotland by using objective measures of green space quantity around participant's home and by subjective measures of local green space use, stress, general health, physical activity, and social well-being. Findings suggested significant positive associations between access to green spaces in the surrounding areas and stress as well as general health [31]. By using panel data (1991 to 2008) from the British Household Panel Survey from over 10,000 individuals living in England, White et al. (2013) investigated potential relations between urban green space and well-being (indexed by ratings of life satisfaction) and between urban green space and mental distress (indexed by GHQ scores). Results were congruent with other studies showing a positive effect of living in urban areas with more green spaces compared to areas with less green spaces on mental health and well-being, even after controlling for individual and regional covariates [43]. Health and well-being benefits of urban allotment gardening was investigated in a case-control study conducted in Manchester, UK by using questionnaires assessing self-esteem, mood, and general health before and after participant's allotment sessions (for the respective questionnaire see Table 4). Results revealed that allotment gardeners had a significantly better self-esteem, total mood disturbance and general health, experienced less depression and fatigue and more vigor [39]. Associations between the quantity and usage of urban green space and health-related quality of life in children were investigated in a study in Edinburgh. The Kid-KINDL questionnaire [56] was used to measure health-related quality of life via self-report. Results showed that among others higher greenspace use was significantly associated with better health-related quality of life in children [28].

However, the attractiveness or amenities of parks might have an influence of its usage, too and hence, better health and well-being. One study protocol was found focusing on the potential impact of refurbishment, renovation, and redesign of parks on health and well-being in New York City, USA. By using thirty intervention park neighborhoods and twenty control park neighborhoods, the study will investigate whether improvements in physical activity, park usage, psychosocial and mental health, and community well-being can be observed among residents in intervention versus control neighborhoods [26]. The same approach will be used in a study conducted in Melbourne, Australia, but is not described here in detail due to our exclusion criteria mentioned in the Methods section [57]. Since the two study protocols were published in 2016 and 2017, no results have been published so far.

To date, the potential influence of blue spaces in cities on UrbWellth is less examined. However, a study conducted in two German cities (Cologne and Düsseldorf) focused on the effect of urban water (the river Rhine) on human health and well-being. Analyses of questionnaires revealed that spending time next to the river enhanced health and well-being $[37,38]$. 
Table 4. Studies on UrbWellth—the morphology sector, years 2007-2017.

\begin{tabular}{|c|c|c|c|c|}
\hline $\begin{array}{l}\text { Authors, Year, } \\
\text { Study Area }\end{array}$ & Study Title & Design & UrbWellth Measurement & Main Findings \\
\hline $\begin{array}{l}\text { Foley et al., } 2017 \text { [23], } \\
\text { Glasgow, Scotland }\end{array}$ & $\begin{array}{l}\text { Effects of living near an urban } \\
\text { motorway on the well-being of } \\
\text { local residents in deprived areas: } \\
\text { natural experimental study }\end{array}$ & $\begin{array}{l}\text { Experimental study } \\
\text { involving longitudinal } \\
\text { cohort }(\mathrm{N}=365) \text { and two } \\
\text { cross-sectional samples } \\
\text { (baseline: } \mathrm{N}=980 ; \\
\text { follow-up: } \mathrm{N}=978 \text { ) }\end{array}$ & $\begin{array}{l}\text { Health and well-being were assessed using mental (MCS- } 8 \text { ) } \\
\text { and physical (PCS-8) components of the SF- } 8 \text {-scale and } \\
\text { the SWEMWBS. }\end{array}$ & $\begin{array}{l}\text { Participants with and without chronic } \\
\text { condition living closer to the motorway } \\
\text { experienced significantly reduced mental } \\
\text { well-being over time compared to those } \\
\text { living further away. }\end{array}$ \\
\hline $\begin{array}{l}\text { Grellier et al., } 2017 \text { [24], } \\
\text { Bulgaria, Czech } \\
\text { Republic, Estonia, } \\
\text { Finland, France, } \\
\text { Germany, Greece, } \\
\text { Ireland, Italy, Portugal, } \\
\text { Spain, Sweden, } \\
\text { Netherlands, UK }\end{array}$ & $\begin{array}{l}\text { BlueHealth: a study program } \\
\text { protocol for mapping and } \\
\text { quantifying the potential benefits to } \\
\text { public health and well-being from } \\
\text { Europe's blue spaces }\end{array}$ & $\begin{array}{l}\text { International European } \\
\text { Panel study, N = still } \\
\text { outstanding }\end{array}$ & $\begin{array}{l}\text { Combination of systematic reviews, analyses of secondary } \\
\text { data sets (e.g., GHQ-12, SF-36, Global Life Satisfaction) and } \\
\text { analyses of new survey data (e.g., well-being measures such } \\
\text { as the WHO-5 Well-being Index and items in the European } \\
\text { Social Survey). Additionally, several community-level } \\
\text { interventions will be conducted and evaluated. }\end{array}$ & Still to be published. \\
\hline $\begin{array}{l}\text { Huang et al., } 2016 \text { [26], } \\
\text { New York City, USA }\end{array}$ & $\begin{array}{l}\text { The Physical Activity and } \\
\text { Redesigned Community Spaces } \\
\text { (PARCS) Study: Protocol of a } \\
\text { natural experiment to investigate } \\
\text { the impact of citywide park } \\
\text { redesign and renovation }\end{array}$ & $\begin{array}{l}\text { Case-control study } \\
\text { design, } \mathrm{N}=30 \\
\text { intervention park } \\
\text { neighborhoods and } \\
\mathrm{N}=20 \text { control park } \\
\text { neighborhoods }\end{array}$ & $\begin{array}{l}\text { A potential impact of park renovation/redesign on its } \\
\text { usage, mental health, and community well-being will be } \\
\text { measured by using data about the sociodemographic } \\
\text { background of study sites, physical activity measured via a } \\
\text { GPS, self-report (using a smartphone-app), and } \\
\text { accelerometers together with survey questions from the } \\
\text { EURO-URHIS } 2 \text { project [58] to measure park satisfaction } \\
\text { and perception, psychosocial and mental health by using } \\
\text { among others the SF-12 and a perceived stress scale, and } \\
\text { finally community well-being (measured e.g., by using } \\
\text { the NEWS). }\end{array}$ & Still to be published. \\
\hline $\begin{array}{l}\text { McCracken et al., } 2016 \\
\text { [28], Edinburgh, } \\
\text { Scotland, UK }\end{array}$ & $\begin{array}{l}\text { Associations between urban } \\
\text { greenspace and health-related } \\
\text { quality of life in children }\end{array}$ & $\begin{array}{l}\text { Cross-sectional survey, } \\
\mathrm{N}=276 \\
\text { (aged 7-13 years) }\end{array}$ & $\begin{array}{l}\text { The Kid-KINDL questionnaire was used to measure } \\
\text { health-related quality of life together with self-report of } \\
\text { usage of greenspace. Quantity of greenspace was measured } \\
\text { by using a GIS, socioeconomic and sociodemographic } \\
\text { covariates were collected via a questionnaire. }\end{array}$ & $\begin{array}{l}\text { Results showed that higher greenspace } \\
\text { use was significantly associated with } \\
\text { better health-related quality of life } \\
\text { in children. }\end{array}$ \\
\hline $\begin{array}{l}\text { Ward-Thompson et al., } \\
2016 \text { [31], Scotland, UK }\end{array}$ & $\begin{array}{l}\text { Mitigating Stress and Supporting } \\
\text { Health in Deprived Urban } \\
\text { Communities: The importance of } \\
\text { Green Space and the Social } \\
\text { Environment }\end{array}$ & $\begin{array}{l}\text { Cross-sectional survey, } \\
\mathrm{N}=406\end{array}$ & $\begin{array}{l}\text { Self-reported stress based on the Perceived Stress Scale } \\
\text { (PSS), mental well-being based on the SWEMWBS together } \\
\text { with a single-item assessment of general health were } \\
\text { primary measures, secondary measures were physical } \\
\text { activity levels and social well-being, all based on self-report. } \\
\text { Additionally, objective and subjective measures on } \\
\text { socioeconomic variables, green space and area-level } \\
\text { deprivation were collected. }\end{array}$ & $\begin{array}{l}\text { Social isolation and place belonging were } \\
\text { strong predictors of stress in three } \\
\text { communities. Another community } \\
\text { showed poor general health. The amount } \\
\text { of green space and access to gardens } \\
\text { were significant predictors of stress. For } \\
\text { instance, physical activity or frequency of } \\
\text { visits to green space in winter were } \\
\text { associated with general health. }\end{array}$ \\
\hline
\end{tabular}


Table 4. Cont.

\begin{tabular}{|c|c|c|c|c|}
\hline $\begin{array}{l}\text { Authors, Year, } \\
\text { Study Area }\end{array}$ & Study Title & Design & UrbWellth Measurement & Main Findings \\
\hline $\begin{array}{l}\text { Wood et al., } 2015 \\
\text { [39], UK }\end{array}$ & $\begin{array}{l}\text { A case-control study of the health } \\
\text { and well-being benefits of allotment } \\
\text { gardening }\end{array}$ & $\begin{array}{l}\text { Case-control study, } \\
\mathrm{N}=269\end{array}$ & $\begin{array}{l}\text { The GHQ-12 was used to assess general health, self-esteem } \\
\text { was assessed using the one-page } 10 \text {-item Rosenberg } \\
\text { self-esteem scale, and mood was assessed using the } 30 \text {-item } \\
\text { POMS questionnaire. }\end{array}$ & $\begin{array}{l}\text { Results revealed that allotment gardeners } \\
\text { had a significantly better self-esteem, } \\
\text { total mood disturbance and general } \\
\text { health, experienced less depression and } \\
\text { fatigue and more vigor. }\end{array}$ \\
\hline $\begin{array}{l}\text { Völker et al., } 2015 \text { [37] } \\
\text { and } 2013 \text { [38], Cologne } \\
\text { and } \\
\text { Düsseldorf, Germany }\end{array}$ & $\begin{array}{l}\text { Developing the urban blue: } \\
\text { Comparative health responses to } \\
\text { blue and green urban open spaces } \\
\text { in Germany / Reprint of: "I'm } \\
\text { always entirely happy when I'm } \\
\text { here!" Urban blue enhancing } \\
\text { human health and well-being in } \\
\text { Cologne and Düsseldorf, Germany }\end{array}$ & $\begin{array}{l}\text { Cross-sectional survey, } \\
\mathrm{N}=113 \text { and } \mathrm{N}=42\end{array}$ & $\begin{array}{l}\text { Semi-standardized qualitative interviews with open } \\
\text { answers. Spatial analyses were conducted using a GIS. }\end{array}$ & $\begin{array}{l}\text { Spending time next to the river enhanced } \\
\text { health and well-being. }\end{array}$ \\
\hline $\begin{array}{l}\text { White et al., } 2013 \\
\text { [43], England }\end{array}$ & $\begin{array}{l}\text { Would You Be Happier Living in a } \\
\text { Greener Urban Area? A } \\
\text { Fixed-Effects Analysis of Panel Data }\end{array}$ & $\begin{array}{l}\text { Panel Survey, } \\
\mathrm{N}=10,168\end{array}$ & $\begin{array}{l}\text { Mental distress was measured with the short-form GHQ-12, } \\
\text { global life satisfaction was assessed with one question. } \\
\text { Additionally, local-area green space data were used. }\end{array}$ & $\begin{array}{l}\text { A positive effect of living in urban areas } \\
\text { with more green spaces compared to } \\
\text { areas with less green spaces on mental } \\
\text { health and well-being, even after } \\
\text { controlling for individual and regional } \\
\text { covariates could be detected. }\end{array}$ \\
\hline $\begin{array}{l}\text { Garvin et al., } 2012 \text { [44], } \\
\text { Philadelphia, } \\
\text { Pennsylvania, USA }\end{array}$ & $\begin{array}{l}\text { More Than Just an Eyesore: Local } \\
\text { Insights and Solutions on Vacant } \\
\text { Land and Urban Health }\end{array}$ & $\begin{array}{l}\text { Cross-sectional survey, } \\
\mathrm{N}=29\end{array}$ & Qualitative interviews with open answers. & $\begin{array}{l}\text { Vacant land affected community } \\
\text { well-being, attracting crime, impacted } \\
\text { physical health through injury and } \\
\text { mental health through anxiety } \\
\text { and stigma. }\end{array}$ \\
\hline $\begin{array}{l}\text { Brown et al., } 2008 \text { [46], } \\
\text { Miami, Florida }\end{array}$ & $\begin{array}{l}\text { Built Environment and Physical } \\
\text { Functioning in Hispanic Elders: } \\
\text { The Role of "Eyes on the Street" }\end{array}$ & $\begin{array}{l}\text { Population-based cohort } \\
\text { study, } \\
\mathrm{N}=273 \text { Hispanics } \\
\text { (aged } \geq 70 \text { years) }\end{array}$ & $\begin{array}{l}\text { Combination of the "built environment" measured by using } \\
\text { the University of Miami Built Environment Coding System } \\
\text { (UMBECS), assessment of social support using three scales, } \\
\text { psychological distress by self-reported anxiety and } \\
\text { depressive symptoms using a 10-item, Spanish version of } \\
\text { the Spielberger State Trait Anxiety Inventory and a 7-item } \\
\text { Depressive Affect subscale of the Center for } \\
\text { Epidemiological Studies Depression Scale together with } \\
\text { measurements of physical functioning and self-rated health. }\end{array}$ & $\begin{array}{l}\text { Architectural features that facilitate } \\
\text { visual and social contacts had a } \\
\text { significant direct relationship with } \\
\text { elder's physical functioning and an } \\
\text { indirect relationship through social } \\
\text { support and psychological distress. }\end{array}$ \\
\hline
\end{tabular}


Grellier et al. (2017) published a study protocol called "BlueHealth". Through systematic reviews, analyses of secondary data sets and analyses of new data collected through a bespoke international survey as well as a wide range of community-level interventions, the "BlueHealth" project shall help to understand the potential relationships between exposure to blue spaces and health and well-being across Europe [24].

Beside green and blue spaces, buildings and built structure or transport infrastructure might influence the UrbWellth of the urban population. In a population-based sample of low socioeconomic status Hispanic elders' potential relationships between the built environment and elder's support, psychological distress, and physical functioning was investigated in an urban community in Miami, USA. Results from the follow-up three years later showed that architectural features that facilitate visual and social contacts had a significant direct relationship with elder's physical functioning and an indirect relationship through social support and psychological distress [46].

Contrary to the building structure, vacant land and its perception and potential influence on health and well-being of inhabitants of Philadelphia, USA was analyzed by Garvin et al. (2012) by conducting semi-structured interviews. Results revealed that vacant land affected community well-being, attracting crime, impacted physical health through injury and mental health through anxiety and stigma [44].

By using a quasi-experimental analysis of a natural experiment, the effects of living near an urban motorway on health and well-being of residents was investigated by Foley et al. (2017) in Glasgow, UK. By using mental (MCS-8) and physical (PCS-8) components of the SF-8-scale and the short Warwick-Edinburgh Mental Well-being Scale (SWEMWBS) at follow up, potential associations between a motorway extension which was constructed through a predominantly urban, deprived area and residents' health and well-being were analyzed. Results revealed that participants living closer to the new motorway experienced significantly reduced mental well-being over time compared to those living further away. Additionally, participants with a chronic condition living closer to the extended motorway showed reduced or poorer mental well-being compared to those living further away [23].

\subsection{Studies on UrbWellth-The Stressors Sector}

Climate change and its influence on health and well-being pose increasing challenges for cities. Heat stress, air pollution or carbon emission, are higher in urban than in rural settings. Hence, humans living in urban areas are at particular risk for higher morbidity and mortality and reduced well-being [59]. To reduce climate change and its threat on UrbWellth, city policies to reduce environmental stressors in urban environments are important components to promote better health and well-being. Furthermore, reduction of greenhouse gas emissions is a relevant step to ensure long-term livability of urban areas by dampening climate change. Although relevant, only two studies matched our inclusion criteria and were selected for this section:

The URGENCHE (Urban Reduction of Greenhouse Gas Emissions in China and Europe) EU-China project investigates potential public health impacts of city policies to reduce greenhouse gas emissions and hence, climate change in five European (Basel, Switzerland, Kuopio, Finland, Rotterdam, Netherlands, Stuttgart, Germany, and Thessaloniki, Greece) and two Chinese (Xi'an and Suzhou) cities [30,60]. By modelling different scenarios using data (year 2010) about carbon dioxide emissions, health impacting exposure (air pollution, noise, and physical activity), health (cardiovascular, respiratory, cancer, and leukemia) and well-being (including noise related well-being, overall well-being, economic well-being, and inequalities) four key findings were found. For instance, reduction of private car use may have benefits for carbon dioxide reduction and positive health impacts through reduced noise and increased physical activity (for more detail see Table 5 and [30]). Health and well-being impacts varied among cities and were often limited due to existing relatively high quality of life and environmental standards in most of the participating cities, suggesting that less developed or developing countries might benefit most from climate change reduction policies [30]. 
Table 5. Studies on UrbWellth—the stressors sector, years 2007-2017.

\begin{tabular}{|c|c|c|c|c|}
\hline $\begin{array}{l}\text { Authors, Year, } \\
\text { Study Area }\end{array}$ & Study Title & Design & UrbWellth Measurement & Main Findings \\
\hline $\begin{array}{l}\text { Sabel et al., } 2016 \text { [30], } \\
\text { Basel, Switzerland, } \\
\text { Kuopio, Finland, } \\
\text { Rotterdam, Netherlands, } \\
\text { Stuttgart, Germany, and } \\
\text { Thessaloniki, Greece, } \\
\text { Xi'an and Suzhou, China }\end{array}$ & $\begin{array}{l}\text { Public health impacts } \\
\text { of city policies to } \\
\text { reduce climate change: } \\
\text { findings from the } \\
\text { URGENCHE } \\
\text { EU-China project }\end{array}$ & $\begin{array}{l}\text { Scenario modelling, } \\
\mathrm{N}=\text { not accessible }\end{array}$ & $\begin{array}{l}\text { Comparative risk assessment was conducted by } \\
\text { calculating DALYs, additionally, well-being cross } \\
\text { sectional surveys were conducted. Information } \\
\text { about levels of carbon dioxide emissions, health } \\
\text { impacting exposures (noise, air pollution or } \\
\text { physical activity), health and well-being were } \\
\text { established for each city together with atmospheric } \\
\text { models and exposure response functions, derived } \\
\text { from epidemiological studies (e.g., the WHO } \\
\text { HRAPIE) to model associations between these } \\
\text { factors and health and well-being in } 2020 \text {. }\end{array}$ & $\begin{array}{l}\text { Four key findings were: } 1 \text {. Introduction of electric } \\
\text { cars might confer some small health benefits; } 2 \text {. } \\
\text { Reduction of private car use might have benefits } \\
\text { for carbon dioxide reduction and positive health } \\
\text { impacts; } 3 \text {. Benefits of carbon dioxide reduction } \\
\text { from increasing housing efficiency are likely to be } \\
\text { minor and benefits for health and well-being } \\
\text { depend on good air exchange; } 4 \text {. Heating homes } \\
\text { by in-home biomass burning might reduce carbon } \\
\text { dioxide emission. However, consequences for } \\
\text { health and well-being were negative with the } \\
\text { technology used in the participating cities. }\end{array}$ \\
\hline $\begin{array}{l}\text { Honold et al., } 2012 \text { [45], } \\
\text { Berlin, Germany }\end{array}$ & $\begin{array}{l}\text { Multiple } \\
\text { environmental } \\
\text { burdens and } \\
\text { neighborhood-related } \\
\text { health of city residents }\end{array}$ & $\begin{array}{l}\text { Cross-sectional } \\
\text { study, } \\
\mathrm{N}=428\end{array}$ & $\begin{array}{l}\text { By using a GIS, street blocks were aggregated to } \\
\text { areas of high, average, and low levels of burden } \\
\text { (using data of noise, air pollution, and green } \\
\text { space). Additionally, household questionnaires } \\
\text { dealing with socioeconomic and } \\
\text { sociodemographic variables and environmental } \\
\text { perception and appraisal were conducted. }\end{array}$ & $\begin{array}{l}\text { Residents from high-burden blocks assessed the } \\
\text { environmental conditions more stressful, reported } \\
\text { poorer health behavior and were less satisfied with } \\
\text { their environmental neighborhood than residents } \\
\text { from low burden blocks. }\end{array}$ \\
\hline
\end{tabular}

DALYs: Disability-adjusted life-years; GIS: Geographical Information System; WHO HRAPIE: World Health Organization Health Risks of Air Pollution in Europe. 
Honold et al. (2012) investigated multiple environmental burdens and their potential influence on self-rated health and well-being in the city of Berlin, Germany. Street blocks with high versus low levels of three environmental burdens (traffic noise, air pollution, and lack of public green space) were identified by conducting spatial analyses and used for a cross-sectional household questionnaire. Results revealed that residents from high-burden blocks assessed the environmental conditions more stressful, reported poorer health behavior, and were less satisfied with their environmental neighborhood than residents from low burden blocks. However, neighborhoods seemed not to be associated with more general health symptoms [45].

\section{Discussion}

This study systematically reviewed published literature (full texts available, English; years 2007 to 2017) on any objective and subjective measurement on health-related well-being in an urban context (UrbWellth). The main findings were summarized based on a systematic literature review conducted by using the two databases PubMed as well as ScienceDirect.

One prerequisite for inclusion of an article in this review was that UrbWellth had to be related to one of the determinants in the sectors or a sector in general: individual, society, morphology or stressors as described in the conceptual model by Szombathely et al. (2017) [14]. Additionally, to allow for comparability and transferability to the conceptual model which focuses on cities from developed countries, only studies were selected which covered European cities or cities located in northern America with a city size from 500,000 to 10 million.

The review showed that subjective urban health and well-being was mostly measured by using the General Health Questionnaire (12 items) (GHQ-12) and the (Short) Warwick-Edinburgh Mental Well-being Scale (S)WEMWBS), respectively. Additionally, to measure subjective well-being the short-form health survey with 8-, 12-, or 36-items was frequently used.

Physical activity and moving patterns were mostly assessed by using the Global Positioning System (GPS). The availability of green spaces or neighborhood deprivation was mostly determined by using a Geographical Information Systems (GIS).

Many studies considered in our review were conducted in the UK suggesting that on the one hand many cities in the UK might have to deal with urban inequalities and disparities. On the other hand stakeholders or other representatives seem to be aware of and recognize the situation, and they seem to be willing to find solutions to reduce these inequalities and improve health and well-being of all urban citizens. Additionally, a greater amount of studies addressing UrbWellth focused on cities in China; these were not included in the current review due to the restriction to North American and European cities.

Although factors and determinants of the other three sectors were largely considered, too, most studies assessed in the review focused on morphology impacts on health and well-being and were thus assigned to the "morphology sector". In particular, the studies which addressed the potential associations between urban green and UrbWellth showed the great importance of green space usage in urban settings to promote better health and well-being. Several reviews, which were found by the systematic literature search, underline the awareness for this relationship. An additional explanation for the high amount of studies dealing with the potential associations between UrbWellth and urban green might be that relevant data (such as landscape or census data) to test these hypotheses are available and easy to obtain or collect.

The systematic literature search showed that many studies use the terms "happiness", "life satisfaction" or "(health-related) quality of life" in the same context as "well-being". Specifically, "well-being" was often equated with "mental health", which made the literature search in many cases difficult and ambiguous because no clear definitions (such as the International Classification of Diseases, ICDs) and necessary delineations were made between health and well-being.

Additionally, literature was found where the term "well-being" was mentioned in relation to health in the title or abstract but was not focused in the text. Therefore, these publications could not be 
considered in our review. The mentioning, however, showed the importance of this term in the general and scientific context.

Since we only used two databases, PubMed and ScienceDirect, for our systematic literature search we cannot rule out a publication bias towards medical (PubMed) and natural or geographical sciences (ScienceDirect). This fact might explain the very few articles found in relation to the environmental stressor sector, where only two publications were considered for inclusion. A systematic literature search in a database with for instance more meteorological focus might have resulted in more relevant articles in this sector.

Furthermore, a language bias might have occurred. Only articles published in English were considered in this review, which might have limited the selected articles. However, because many researchers publish in international English written journals for better distribution of their work this bias might be negligible. Moreover, only full and available publications were included. Hence, the search may have missed some relevant articles.

The conceptual model, which was used as a basis for this review clearly focuses on cities from developed regions. Hence, we focused our systematic literature search on studies conducted in European cities or cities located in northern America. This clearly biases our results to more wealthy regions and limits transferability to other regions. Studies from less developed countries might have a completely different focus on urban health and well-being and hence, different measurements and results. For example, public infrastructure such as sanitation, which is taken granted in northern America or European cities, can act as a crucial variable in influencing health and hence, well-being in an urban society with relatively poor sanitation, especially in informal settings.

Apart from studies focusing on urban mental health and/or well-being, there is still a lack in studies investigating other (urban) diseases and consequently well-being. Traffic noise for instance, which in general is more frequent in urban than in rural areas, is known to be associated with several health outcomes. Hence, it might possibly be associated with well-being. For example, results from the KORA study (Cooperative health research in the Region of Augsburg), Germany, showed higher prevalence for hypertension with an increase in traffic noise (odds ratio for a 10-dB (A) increase $=1.16(95 \%$ CI: 1.00, 1.35) [16]. Other studies showed associations between environmental noise and respiratory disease such as asthma [61] or mental disorders [62,63]. Exposure to gaseous (carbon monoxide, sulphur dioxide, nitrogen dioxide, ozone) and particulate $\left(\mathrm{PM}_{2.5}\right.$ or $\left.\mathrm{PM}_{10}\right)$ air pollutants has been associated with several health outcomes such as heart failure [64] or chronic respiratory diseases [19]. However, the main outcomes of these studies are health-related, none of these studies investigated potential associations between objective indicators for urban health and well-being. This could also be seen during the literature search which resulted in only two studies to be considered in the environmental "stressors sector". Contrary, a study using objective indicators to measure urban "quality of life" without considering health was conducted by Wẹziak-Bialowolska (2016) by using the "Flash Eurobarometer 366: Quality of life in European cities" [65]. Survey data from 79 European cities were used that describe for instance the availability of public transport, health care services, air quality, noise levels, security, and other factors. This enabled analyses of associations between citizen characteristics, neighborhoods and well-being or life satisfaction in a city and showed great differences among the cities.

Walkability, which has been shown to be associated with better physical health [66] or human well-being [67], has been a popular topic of research in recent years. Several reviews addressed already the influence of the neighborhood environment on walkability $[68,69]$. Additionally, the term "Walkability" is not covered by the conceptual model. Therefore, we did not focus on papers dealing with associations of walkability and health or well-being. However, one study, conducted in Tucson, Arizona, United States, shall be mentioned in this context, addressing the potential impact of four neighborhood design types on physical activity together with well-being by using the Walkability Model. Results showed that among others the traditional development design was associated with the highest value for walkability. The suburban development showed significant associations and the 
highest mean values for mental health and well-being. Cluster housing was significantly associated with highest mean value for social interactions with neighbors and for perceived safety from crime. Enclosed communities did not obtain the highest means for any well-being benefit. Finally, this article outlined the importance of including vegetation throughout neighborhoods to increase physical activity and well-being [70].

Finally, a fairly new approach to measure and improve health and well-being of urban population, the so-called "Internet of Things" (IoT), shall be mentioned in the context of UrbWellth [71-73]. By connecting all citizens via sensors and devices with the Internet, citizens' health and well-being might be improved by a variety of ways. This includes for instance the health of older inhabitants via a smartphone app as it was conducted in Barcelona, Spain [74,75] or via the "Games for Health", as it has been shown in Finland [76,77].

\section{Conclusions}

Our extensive literature search on UrbWellth showed that in times of rapid urbanization, health and well-being of citizens are increasingly recognized as a challenge and that a remarkable amount of research on the potential associations between urban areas and health or well-being has been conducted. However, there are still only few studies investigating the great complexity of urban health and well-being. More specifically, there is a lack in interdisciplinary approaches that highlight the complexity of urban structures and dynamics and their possible influence on urban health and well-being (UrbWellth). Most promising publications for this issue are study protocols with results still to be published, showing on the one side, the recognized importance of this topic, but on the other side, the still poorly researched interrelations. However, especially these results might be of interest for city planners, architects, health scientists, and many other disciplines to develop further strategies to reduce health inequalities and to better promote urban health and well-being.

Acknowledgments: The authors wish to thank Pia Dahlhoff, Sara Tiedemann, and Mario Gehoff as part of the scientific communications team of the IVDP for copy editing. Additionally, we would like to thank Nirohshah Suthakharan for reading and improving the final manuscript. This contribution is based on the work of the research project "Cities in Change-Development of a multi-sectoral urban-development-impact model (UrbMod)", a joint project of University of Hamburg, Hamburg University of Technology, University Medical Center Hamburg-Eppendorf, Institute of Coastal Research at Helmholtz Center Geesthacht, Max-Planck-Institute for Meteorology, and Hafen-City University, funded by the State of Hamburg.

Author Contributions: Anne Caroline Krefis performed the systematic literature search and wrote the manuscript; Jobst Augustin, Matthias Augustin, Katharina Heinke Schlünzen, and Jürgen Oßenbrügge contributed to the framework of this systematic literature search and reviewed the paper.

Conflicts of Interest: The authors declare no conflict of interest.

\section{References}

1. United Nations, Department of Economic and Social Affairs, Population Division. World Urbanization Prospects: The 2014 Revision, CD-ROM Edition; United Nations, Department of Economic and Social Affairs, Population Division: New York, NY, USA, 2014.

2. Burdett, R.; Taylor, M.; Kaasa, A. Cities, Health and Well-Being: Conference newspaper. In Proceedings of the Hong Kong Urban Age Conference, Hong Kong, China, 16-17 November 2011; pp. 3-44.

3. Galea, S.; Freudenberg, N.; Vlahov, D. Cities and population health. Soc. Sci. Med. 2005, 60, 1017-1033. [CrossRef] [PubMed]

4. Rydin, Y.; Bleahu, A.; Davies, M.; Dávila, J.D.; Friel, S.; de Grandis, G.; Groce, N.; Hallal, P.C.; Hamilton, I.; Howden-Chapman, P.; et al. Shaping cities for health: Complexity and the planning of urban environments in the 21st century. Lancet 2012, 379, 2079-2108. [CrossRef]

5. Vlahov, D.; Galea, S. Urban health: A new discipline. Lancet 2003, 362, 1091-1092. [CrossRef] 
6. Taylor, M. Cities, health and well-being: Report on a conference organised by LSE Cities at the London School of Economics and Political Science and the Alfred Herrhausen Society, in partnership with the University of Hong Kong. In Proceedings of the Urban Age Conference, Hong Kong, China, 16-17 November 2011; pp. 1-10.

7. Healthy People 2020. Health-Related Quality of Life and Well-Being. Available online: https://www. healthypeople.gov/2020/topics-objectives/topic/health-related-quality-of-life-well-being (accessed on 27 June 2017).

8. ICSU. Science Plan on Health and Wellbeing in the Changing Urban Environment: A Systems Approach; ICSU: Paris, France, 2011; Available online: https:/ / www.icsu.org/cms/2017/05/Health-and-wellbeing-in-thechanging-urban-environment-web.pdf (accessed on 20 June 2017).

9. Bai, X.; Nath, I.; Capon, A.; Hasan, N.; Jaron, D. Health and wellbeing in the changing urban environment: Complex challenges, scientific responses, and the way forward. Curr. Opin. Environ. Sustain. 2012, 4, 465-472. [CrossRef]

10. World Health Organization Regional Office for Europe. National Healthy Cities Networks in the WHO European Region-Promoting Health and Well-Being throughout Europe. Available online: http:/ / www.euro.who.int/_data/assets/pdf_file/0011/285995/Healthy-Cities-promoting-healthand-equity.pdf (accessed on 19 April 2016).

11. Dodge, R.; Daly, A.; Huyton, J.; Sanders, L. The challenge of defining wellbeing. Int. J. Wellbeing 2012, 2, 222-235. [CrossRef]

12. Alatartseva, E.; Barysheva, G. Well-being: Subjective and Objective Aspects. Procedia-Soc. Behav. Sci. 2015, 166, 36-42. [CrossRef]

13. Ballas, D. What makes a 'happy city'? Cities 2013, 32, S39-S50. [CrossRef]

14. Von Szombathely, M.; Albrecht, M.; Antanaskovic, D.; Augustin, J.; Augustin, M.; Bechtel, B.; Bürk, T.; Fischereit, J.; Grawe, D.; Hoffmann, P.; et al. A Conceptual Modeling Approach to Health-Related Urban Well-Being. Urban Sci. 2017, 1, 17. [CrossRef]

15. Marans, R.W. Quality of urban life \& environmental sustainability studies: Future linkage opportunities. Habitat Int. 2015, 45, 47-52. [CrossRef]

16. Babisch, W.; Wolf, K.; Petz, M.; Heinrich, J.; Cyrys, J.; Peters, A. Associations between Traffic Noise, Particulate Air Pollution, Hypertension, and Isolated Systolic Hypertension in Adults: The KORA Study. Environ. Health Perspect. 2014, 122, 492-498. [CrossRef] [PubMed]

17. Jarup, L.; Babisch, W.; Houthuijs, D.; Pershagen, G.; Katsouyanni, K.; Cadum, E.; Dudley, M.-L.; Savigny, P.; Seiffert, I.; Swart, W.; et al. Hypertension and Exposure to Noise Near Airports: The HYENA Study. Environ. Health Perspect. 2007, 116, 329-333. [CrossRef] [PubMed]

18. Pascal, M.; Corso, M.; Chanel, O.; Declercq, C.; Badaloni, C.; Cesaroni, G.; Henschel, S.; Meister, K.; Haluza, D.; Martin-Olmedo, P.; et al. Assessing the public health impacts of urban air pollution in 25 European cities: Results of the Aphekom project. Sci. Total Environ. 2013, 449, 390-400. [CrossRef] [PubMed]

19. Faustini, A.; Stafoggia, M.; Berti, G.; Bisanti, L.; Chiusolo, M.; Cernigliaro, A.; Mallone, S.; Primerano, R.; Scarnato, C.; Simonato, L.; et al. The relationship between ambient particulate matter and respiratory mortality: A multi-city study in Italy. Eur. Respir. J. 2011, 38, 538-547. [CrossRef] [PubMed]

20. Larson, L.R.; Jennings, V.; Cloutier, S.A. Public Parks and Wellbeing in Urban Areas of the United States. PLoS ONE 2016, 11, e0153211. [CrossRef] [PubMed]

21. Bertram, C.; Rehdanz, K. The Role of Urban Green Space for Human Well-Being. Ecol. Econ. 2015, 120, 139-152. [CrossRef]

22. Pedersen, E. City dweller responses to multiple stressors intruding into their homes: Noise, light, odour, and vibration. Int. J. Environ. Res. Public Health 2015, 12, 3246-3263. [CrossRef] [PubMed]

23. Foley, L.; Prins, R.; Crawford, F.; Humphreys, D.; Mitchell, R.; Sahlqvist, S.; Thomson, H.; Ogilvie, D. Effects of living near an urban motorway on the wellbeing of local residents in deprived areas: Natural experimental study. PLoS ONE 2017, 12, e0174882. [CrossRef] [PubMed]

24. Grellier, J.; White, M.P.; Albin, M.; Bell, S.; Elliott, L.R.; Gascón, M.; Gualdi, S.; Mancini, L.; Nieuwenhuijsen, M.J.; Sarigiannis, D.A.; et al. BlueHealth: A study programme protocol for mapping and quantifying the potential benefits to public health and well-being from Europe's blue spaces. BMJ Open 2017, 7, 1-10. [CrossRef] [PubMed] 
25. Hogan, M.J.; Leyden, K.M.; Conway, R.; Goldberg, A.; Walsh, D.; McKenna-Plumley, P.E. Happiness and health across the lifespan in five major cities: The impact of place and government performance. Soc. Sci. Med. 2016, 162, 168-176. [CrossRef] [PubMed]

26. Huang, T.T.K.; Wyka, K.E.; Ferris, E.B.; Gardner, J.; Evenson, K.R.; Tripathi, D.; Soto, G.M.; Cato, M.S.; Moon, J.; Wagner, J.; et al. The Physical Activity and Redesigned Community Spaces (PARCS) Study: Protocol of a natural experiment to investigate the impact of citywide park redesign and renovation. BMC Public Health 2016, 16, 1160. [CrossRef] [PubMed]

27. Kestens, Y.; Chaix, B.; Gerber, P.; Desprès, M.; Gauvin, L.; Klein, O.; Klein, S.; Köppen, B.; Lord, S.; Naud, A.; et al. Understanding the role of contrasting urban contexts in healthy aging: An international cohort study using wearable sensor devices (the CURHA study protocol). BMC Geriatr. 2016, 16, 96. [CrossRef]

28. McCracken, D.S.; Allen, D.A.; Gow, A.J. Associations between urban greenspace and health-related quality of life in children. Prev. Med. Rep. 2016, 3, 211-221. [CrossRef] [PubMed]

29. Ram, B.; Nightingale, C.M.; Hudda, M.T.; Kapetanakis, V.V.; Ellaway, A.; Cooper, A.R.; Page, A.; Lewis, D.; Cummins, S.; Giles-Corti, B.; et al. Cohort profile: Examining Neighbourhood Activities in Built Living Environments in London: The ENABLE London-Olympic Park cohort. BMJ Open 2016, 6, e012643. [CrossRef] [PubMed]

30. Sabel, C.E.; Hiscock, R.; Asikainen, A.; Bi, J.; Depledge, M.; van den Elshout, S.; Friedrich, R.; Huang, G.; Hurley, F.; Jantunen, M.; et al. Public health impacts of city policies to reduce climate change: Findings from the URGENCHE EU-China project. Environ. Health 2016, 15 (Suppl. S1), 25. [CrossRef] [PubMed]

31. Ward Thompson, C.; Aspinall, P.; Roe, J.; Robertson, L.; Miller, D. Mitigating Stress and Supporting Health in Deprived Urban Communities: The Importance of Green Space and the Social Environment. Int. J. Environ. Res. Public Health 2016, 13, 440. [CrossRef] [PubMed]

32. Egan, M.; Lawson, L.; Kearns, A.; Conway, E.; Neary, J. Neighbourhood demolition, relocation and health. A qualitative longitudinal study of housing-led urban regeneration in Glasgow, UK. Health Place 2015, 33, 101-108. [CrossRef] [PubMed]

33. Egan, M.; Kearns, A.; Mason, P.; Tannahill, C.; Bond, L.; Coyle, J.; Beck, S.; Crawford, F.; Hanlon, P.; Lawson, L.; et al. Protocol for a mixed methods study investigating the impact of investment in housing, regeneration and neighbourhood renewal on the health and wellbeing of residents: The GoWell programme. BMC Med. Res. Methodol. 2010, 10, 41. [CrossRef] [PubMed]

34. Harding, S.; Read, U.M.; Molaodi, O.R.; Cassidy, A.; Maynard, M.J.; Lenguerrand, E.; Astell-Burt, T.; Teyhan, A.; Whitrow, M.; Enayat, Z.E. The Determinants of young Adult Social well-being and Health (DASH) study: Diversity, psychosocial determinants and health. Soc. Psychiatry Psychiatr. Epidemiol. 2015, 50, 1173-1188. [CrossRef] [PubMed]

35. Hayward, E.; Ibe, C.; Young, J.H.; Potti, K.; Jones, P.; Pollack, C.E.; Gudzune, K.A. Linking social and built environmental factors to the health of public housing residents: A focus group study. BMC Public Health 2015, 15, 351. [CrossRef] [PubMed]

36. Smith, N.R.; Lewis, D.J.; Fahy, A.; Eldridge, S.; Taylor, S.J.C.; Moore, D.G.; Clark, C.; Stansfeld, S.A.; Cummins, S. Individual socio-demographic factors and perceptions of the environment as determinants of inequalities in adolescent physical and psychological health: The Olympic Regeneration in East London (ORiEL) study. BMC Public Health 2015, 15, 150. [CrossRef] [PubMed]

37. Völker, S.; Kistemann, T. Developing the urban blue: Comparative health responses to blue and green urban open spaces in Germany. Health Place 2015, 35, 196-205. [CrossRef] [PubMed]

38. Völker, S.; Kistemann, T. "I'm always entirely happy when I'm here!” Urban blue enhancing human health and well-being in Cologne and Düsseldorf, Germany. Soc. Sci. Med. 2013, 78, 113-124. [CrossRef] [PubMed]

39. Wood, C.J.; Pretty, J.; Griffin, M. A case-control study of the health and well-being benefits of allotment gardening. J. Public Health 2016, 38, e336-e344. [CrossRef] [PubMed]

40. Green, J.; Jones, A.; Roberts, H. More than A to B: The role of free bus travel for the mobility and wellbeing of older citizens in London. Ageing Soc. 2014, 34, 472-494. [CrossRef] [PubMed]

41. Phillips, G.; Bottomley, C.; Schmidt, E.; Tobi, P.; Lais, S.; Yu, G.; Lynch, R.; Lock, K.; Draper, A.; Moore, D.; et al. Measures of exposure to the Well London Phase-1 intervention and their association with health well-being and social outcomes. J. Epidemiol. Community Health 2014, 68, 597-605. [CrossRef] [PubMed] 
42. Phillips, G.; Bottomley, C.; Schmidt, E.; Tobi, P.; Lais, S.; Yu, G.; Lynch, R.; Lock, K.; Draper, A.; Moore, D.; et al. Well London Phase-1: Results among adults of a cluster-randomised trial of a community engagement approach to improving health behaviours and mental well-being in deprived inner-city neighbourhoods. J. Epidemiol. Community Health 2014, 68, 606-614. [CrossRef] [PubMed]

43. White, M.P.; Alcock, I.; Wheeler, B.W.; Depledge, M.H. Would you be happier living in a greener urban area? A fixed-effects analysis of panel data. Psychol. Sci. 2013, 24, 920-928. [CrossRef] [PubMed]

44. Garvin, E.; Branas, C.; Keddem, S.; Sellman, J.; Cannuscio, C. More than just an eyesore: Local insights and solutions on vacant land and urban health. J. Urban Health 2013, 90, 412-426. [CrossRef] [PubMed]

45. Honold, J.; Beyer, R.; Lakes, T.; van der Meer, E. Multiple environmental burdens and neighborhood-related health of city residents. J. Environ. Psychol. 2012, 32, 305-317. [CrossRef]

46. Brown, S.C.; Mason, C.A.; Perrino, T.; Lombard, J.L.; Martinez, F.; Plater-Zyberk, E.; Spokane, A.R.; Szapocznik, J. Built environment and physical functioning in Hispanic elders: The role of "eyes on the street". Environ. Health Perspect. 2008, 116, 1300-1307. [CrossRef] [PubMed]

47. Kuh, D.; Ben Shlomo, Y. A life Course Approach to Chronic Disease Epidemiology, 2nd ed.; Oxford University Press: Oxford, NY, USA, 2004.

48. Institute of Community Health Sciences. Health of Young People in East London-The Relachs Study. Available online: http:/ / archive.wolfson.qmul.ac.uk/relachs/academics/publications/Relachs_report.pdf (accessed on 10 August 2017).

49. Fagg, J.; Curtis, S.; Stansfeld, S.; Congdon, P. Psychological distress among adolescents, and its relationship to individual, family and area characteristics in East London. Soc. Sci. Med. 2006, 63, 636-648. [CrossRef] [PubMed]

50. Goodman, A.; Patel, V.; Leon, D.A. Child mental health differences amongst ethnic groups in Britain: A systematic review. BMC Public Health 2008, 8, 258. [CrossRef] [PubMed]

51. Stansfeld, S.A.; Haines, M.M.; Head, J.A.; Bhui, K.; Viner, R.; Taylor, S.J.; Hillier, S.; Klineberg, E.; Booy, R. Ethnicity, social deprivation and psychological distress in adolescents: School-based epidemiological study in east London. Br. J. Psychiatry 2004, 185, 233-238. [CrossRef] [PubMed]

52. D'Alessandro, D.; Buffoli, M.; Capasso, L.; Fara, G.M.; Rebecchi, A.; Capolongo, S. Green areas and public health: Improving wellbeing and physical activity in the urban context. Epidemiol. Prev. 2015, 39, 8-13. [PubMed]

53. Salmond, J.A.; Tadaki, M.; Vardoulakis, S.; Arbuthnott, K.; Coutts, A.; Demuzere, M.; Dirks, K.N.; Heaviside, C.; Lim, S.; Macintyre, H.; et al. Health and climate related ecosystem services provided by street trees in the urban environment. Environ. Health 2016, 15 (Suppl. S1), 36. [CrossRef] [PubMed]

54. Wolf, K.L.; Robbins, A.S.T. Metro nature, environmental health, and economic value. Environ. Health Perspect. 2015, 123, 390-398. [CrossRef] [PubMed]

55. Tzoulas, K.; Korpela, K.; Venn, S.; Yli-Pelkonen, V.; Kaźmierczak, A.; Niemela, J.; James, P. Promoting ecosystem and human health in urban areas using Green Infrastructure: A literature review. Landsc. Urban Plan. 2007, 81, 167-178. [CrossRef]

56. Ravens-Sieberer, U.; Bullinger, M. Assessing health-related quality of life in chronically ill children with the German KINDL: First psychometric and content analytical results. Qual. Life Res. 1998, 7, 399-407. [CrossRef] [PubMed]

57. Dobbinson, S.J.; Veitch, J.; Salmon, J.; Wakefield, M.; Staiger, P.K.; MacInnis, R.J.; Simmons, J. Study protocol for a natural experiment in a lower socioeconomic area to examine the health-related effects of refurbishment to parks including built-shade (ShadePlus). BMJ Open 2017, 7, e013493. [CrossRef] [PubMed]

58. Pope, D.; Tisdall, R.; Middleton, J.; Verma, A.; van Ameijden, E.; Birt, C.; Macherianakis, A.; Bruce, N.G. Quality of and access to green space in relation to psychological distress: Results from a population-based cross-sectional study as part of the EURO-URHIS 2 project. Eur. J. Public Health 2018, 28, 35-38. [CrossRef] [PubMed]

59. IPCC. Summary for Policymakers. Available online: https://www.ipcc.ch/pdf/assessment-report/ar5/ wg2/ar5_wgII_spm_en.pdf (accessed on 11 September 2017).

60. Hiscock, R.; Mudu, P.; Braubach, M.; Martuzzi, M.; Perez, L.; Sabel, C. Wellbeing impacts of city policies for reducing greenhouse gas emissions. Int. J. Environ. Res. Public Health 2014, 11, 12312-12345. [CrossRef] [PubMed] 
61. Duhme, H.; Weiland, S.K.; Keil, U.; Kraemer, B.; Schmid, M.; Stender, M.; Chambless, L. The association between Self-Reported Symptoms of Asthma and Allergic Rhinitis and Self-Reported Traffic Density on Street of Residence in Adolescents. Epidemiology 1996, 6, 578-582. [CrossRef]

62. Hiramatsu, K.; Yamamoto, T.; Taira, K.; Ito, A.; Nakasone, T. A Survey on Health Effects due to Aircraft Noise on Residents Living Around Kadena Air Base in the Ryukyus. J. Sound Vib. 1997, 205, 451-460. [CrossRef]

63. Yoshida, T.; Osada, Y.; Kawaguchi, T.; Hoshiyama, Y.; Yoshida, K.; Yamamoto, K. Effects of Road Traffic Noise on Inhabitants of Tokyo. J. Sound Vib. 1997, 205, 517-522. [CrossRef]

64. Dominici, F.; Peng, R.D.; Bell, M.L.; Pham, L.; McDermott, A.; Zeger, S.L.; Samet, J.M. Fine Particulate Air Pollution and Hospital Admission for Cardiovascular and Respiratory Diseases. JAMA 2006, 295, 1127. [CrossRef] [PubMed]

65. Węziak-Białowolska, D. Quality of life in cities-Empirical evidence in comparative European perspective. Cities 2016, 58, 87-96. [CrossRef]

66. Inoue, S.; Ohya, Y.; Odagiri, Y.; Takamiya, T.; Ishii, K.; Kitabayashi, M.; Suijo, K.; Sallis, J.F.; Shimomitsu, T. Association between Perceived Neighborhood Environment and Walking among Adults in 4 Cities in Japan. J. Epidemiol. 2010, 20, 277-286. [CrossRef] [PubMed]

67. Jaśkiewicz, M.; Besta, T. Is Easy Access Related to Better Life? Walkability and Overlapping of Personal and Communal Identity as Predictors of Quality of Life. Appl. Res. Qual. Life 2014, 9, 505-516. [CrossRef] [PubMed]

68. Saelens, B.E.; Handy, S.L. Built environment correlates of walking: A review. Med. Sci. Sports Exerc. 2008, 40, S550-S566. [CrossRef] [PubMed]

69. Talen, E.; Koschinsky, J. The Walkable Neighborhood: A Literature Review. Int. J. Sustain. Land Use Urban Plan. 2013, 1, 42-63. [CrossRef]

70. Zuniga-Teran, A.A.; Orr, B.J.; Gimblett, R.H.; Chalfoun, N.V.; Guertin, D.P.; Marsh, S.E. Neighborhood Design, Physical Activity, and Wellbeing: Applying the Walkability Model. Int. J. Environ. Res. Public Health 2017, 14, 76. [CrossRef] [PubMed]

71. Ashton, K. That 'Internet of Things' Thing. RFID J. 2009, 22, 97-114.

72. Kamel Boulos, M.N.; Al-Shorbaji, N.M. On the Internet of Things, smart cities and the WHO Healthy Cities. Int. J. Health Geogr. 2014, 13, 1-6. [CrossRef] [PubMed]

73. Kamel Boulos, M.N.; Tsouros, A.D.; Holopainen, A. 'Social, innovative and smart cities are happy and resilient': Insights from the WHO EURO 2014 International Healthy Cities Conference. Int. J. Health Geogr. 2015, 14, 3. [CrossRef] [PubMed]

74. Almansa, J. “Vincles BCN”, a Project against Isolation of Senior Citizens, Winner of Bloomberg Mayors Challenge: Mobile World Capital Barcelona. Available online: http://mobileworldcapital.com/684/ (accessed on 21 August 2017).

75. Alcaraz, T.G. Could New Technology Help Older People in Barcelona Create Stronger Networks? Available online: https: / / www.theguardian.com/cities /2014/oct/28/could-new-technology-help-older-people-inbarcelona-create-stronger-networks (accessed on 21 August 2017).

76. Kamel Boulos, M.N. Xbox 360 Kinect Exergames for Health. Games Health J. 2012, 1, 326-330. [CrossRef] [PubMed]

77. Holopainen, A.; Arpola, T.; Wuorisalo, J. Games for Health—Finland. Available online: https:/ / de.slideshare. net/gamesforhealthfinland/health-tuesday-games-for-health-finland (accessed on 21 August 2017).

(C) 2018 by the authors. Licensee MDPI, Basel, Switzerland. This article is an open access article distributed under the terms and conditions of the Creative Commons Attribution (CC BY) license (http://creativecommons.org/licenses/by/4.0/). 